\title{
The Role of Structural Contexts of the Pahlavi Government and Shiite Political Islam in the Formation of the Iran Revolution in 1979
}

\author{
Aref Barkhordari \\ Department of Political Thought. University of Tehran \\ Tehran. Iran \\ Email: arefbarkhordari [AT] ut.ac.ir
}

\begin{abstract}
The present paper with an analytical-descriptive method is based on the theory of the collective behavior of Smelser in response to the question of how the Pahlavi government's structural background influenced the formation of the 1979 Islamic Revolution of Iran. Before the Islamic Revolution, Iran, like other societies, was composed a set of structures. The actions of the Pahlavi discourse triggered the stressors within these structures and eventually created gaps and conflicts in them. In such circumstances, a kind of structural unbalance arose. As a result, it put pressure on social forces and made the situation unjust, inefficient, and retarded in the public's view. These social forces were disintegrated and social groupings emerged, which created a volatile situation and, consequently, favorable conditions for collective movement in society. In this regard, ideas were formed that sought change and justice in Iran. Shiite political Islam was more effective than any other public belief and with the leadership of Ayatollah Khomeini and with the accelerating factors towards the revolution; it provided the conditions for revolutionary developments in Iran and ultimately led to the formation of the Islamic Revolution of Iran.
\end{abstract}

Keywords--- Shiite Political Islam, Revolution, Conflicts, Structures, Gaps

\section{INTRODUCTION AND THEORETICAL FRAMEWORK}

The term revolution comes from the word transformation meaning subversion, transformation and change (Moein, 1981). The word revolution has a new use in its political meaning, which is equivalent to transformation and change or overthrow. Initially, the term was used in astronomy. In the common term of the world, revolution is the attempt of some to overthrow the government and create a new government in order to make fundamental changes in all institutions, relations of political and social structure and to replace the new and desirable organization within the framework with specific goals and ideals.

The complication of the phenomenon of revolution, like other important political and social concepts, caused controversy among social thinkers about the meaning and concept of revolution. Some consider the only political changes that lead to the turning of history or the emergence and development of attitudes completely different from the traditional order as a revolution. Some distinguish between a political revolution and a social revolution (Bashiriye, 2014: 4-5) and revolution in the above sense is called only a special kind of revolution, that is, social revolution, and the important political changes that follow some other changes and change the policies, Social statuses and ideology of the ruling group are called political revolutions.

The concept of revolution, like many other social phenomena, does not have a single and unified definition among all and several definitions of revolution are provided. The definitions of revolution can be divided into three categories: the group that defined the revolution based on the intentions of the revolutionaries. The second group has identified the revolution based on its results and consequences, and according to the third group, the revolution as a process has been studied and defined (Moshirzadeh, 1995: 15). Similarly, different views on the "why" and "how" the revolution have been proposed and explained by thinkers. "Some see revolutions as the inevitable result of social structure in historical periods. "Another group, relying on 'pragmatism', denies the necessity of revolution because of the objectivity of social stability." Some also believe that the "mass society", which is based on the traditional stability of certain structures, will tend towards a popular revolution if it is confronted with the destruction of its structures. "Another group, using the justifications of social psychology, tries to identify the motives for the 'uprising against the established rulers' or Non-realization of the masses imaginations throughout their lives (Rajabloo, 1996). These groups have presented a wide range of ideas about revolution, and thinkers such as Chalmers Johnson, Hannah Arendt, William Kornhauser, James Davis, Garr, Petrim Sorokin, Huntington, Crane Brinton, Teda Scotchpool, and Neil Smelser have discussed the revolution. Which we refuse to mention.

Despite the lack of an agreed definition, a revolution can be characterized by the following characteristics: deep dissatisfaction with the prevailing conditions, the spread of new ideology (s), revolutionary spirit, socio-political structures with role and mobilizer, popular participation (although Part of the people), violent struggle and the sudden replacement 
of one group with a new ideology instead of another. Also, the main and distinguishing elements of the phenomenon of revolution from other social developments can be considered in the following issues: violence and revolt, being popular, leadership and organization, and ideology.

As explained earlier, different thinkers have discussed the reasons for the formation, why, and how the revolution took place. One of the thinkers who discussed revolution was Neil Smelser, who analyzed his theory of revolution in his book The Theory of Collective Behavior. In the following, after examining Smelser's theory of collective behavior regarding the revolution, we will examine the 1979 Islamic Revolution of Iran in the form of this theory.Behavior is defined as the usual way of action and human life. In psychology, too, a person's reaction is defined as behavior. "Collective behavior is unstructured, spontaneous, emotional, and unpredictable behavior patterns" (Coen, 2005: 323). Robert Park describes collective behavior as follows: "Collective behavior derives from any human gathering in which every individual is driven into action or thought through creating or of a mental situation in which everyone makes a share or has participated in its formation." (Julius and Columbus, 1997: 442). Neil Smelser believes that collective behavior is an uninstitutional mobilization to rebuild part of the action, based on a generalized belief (Smesler, 2001: 12). He defines social action as the regular effort of an actor who, in the context of the environment or situation, seeks to achieve the desired goal or goals. Neil Smelser considers forms of collective behavior to include the following emotions: panics, mass hysteria (mass crazes, business boom, situational and religious revivalism), hostile riots, normative movement (including expression movement), and Value-oriented movement (including political and religious revolution, formation of sects and nationalist movements, etc.). In the following, he mentions six conditions as the primary determinants of collective behavior: structural background, structural pressure, generalized belief, accelerating factors, mobilization for action, social control operations (Smesler, 2001: 20-20).

It has been said that the political revolution is a value oriented movement. For the formation of a collective behavior naming revolution, the structural background of that society must be conducive to public mobilization and collective behavior. If we are to consider the stages for a revolution, these are: 1 . Turbulent structural contexts are imposed by some active measures, and pressures on society and social forces; 2 . The forces are encouraged to work together to find a solution; 3. People accept belief or value as an alternative to pursue justice in society and to provide a solution as a generalized belief; 4. Certain accelerating factors in collective behavior cause society to collectively mobilize and mobilize; 5. At this stage, the leadership will mobilize the activists; 6. Finally, the forces of social control and suppression in the system lose the necessary power to prevent and suppress collective behavior, and a revolution is formed.

Thus, the structural contexts of any society are the starting point for collective behavior and public mobilization leading to a revolution. So, we have to find out what the structural background is.

Structural context means that the structure of society must be such that a particular form of collective behavior occurs within it (Coen, 2005: 327-324; smelser 2001: 20-20). In his book Theory of Collective Behavior in Defining Structural Terms and Contexts, Smelser writes: "Structural contexts are the general social conditions or factors and conditions that exist in the political, economic, cultural, and social construction of the existing system and, if they grow or continue, they cause tension and conflict in the community."(Sabbagh Jadid: 32-51). Elsewhere he states: "Structural favorable contexts are the favorable general social conditions necessary for the formation of collective behavior. Structural favorable conditions at its highest level allow for the emergence of a particular type of collective behavior and stherefore, a favorable structural context must exist to form a collective behavior, for example, if there is no racial and ethnic discrimination in society, the Structural background for racial movements wouldn't be suitable."(ibid).

Structural context is the general social conditions or stressful contexts within a society's structures that, if activated, cause conflicts and gaps in those structures. These divisions and conflicts put pressure on social forces and groups and make them unsatisfied. Then social forces disintegrated and social groupings emerge. Then, there is the protest and the collective action of the individuals in the community. Therefore, if there is a stressful structural background in political, economic, social, cultural and religious structures and activated by some actions, conflicts will arise and pressures will be inflicted on some people in society, and they understand the political, economic, social, cultural, and religious deprivations brought about by these pressures, resulting in dissatisfaction and conflict of interest, thereby creating an appropriate ground for revolutionary movement and collective behavior.

The 1979 Islamic Revolution in Iran (Barkhordari, 2020(a):23-24) is no exception to this rule. Given that the policies and practices of the first and second Pahlavi governments were not in line with the culture and structures of traditional Iranian society, these actions activated tensions within the political, economic, social, cultural, and religious structures of Iranian society and subsequently created gaps and conflicts in these Structures. This, in turn, created pressures on the system and the social forces and individuals of the community, and the situation seemed unjust and ineffective for them. Consequently, a suitable structural background was provided for the formation of collective movement.

In the area of economic and social structures, factors such as rapid urbanization, the development of higher education, the disruption of norms and values, the dependent development and the spread of inequality, have been the cause of structural pressure and a sense of social and economic deprivation. In terms of religious and cultural structures, the Pahlavi government's actions threatened the Shiite cultural and Shiite identity and divided it and, as a result, created tension in the religious and cultural affairs of the people and society. Along such tensions and pressures imposed on the system and social 
forces, this situation appeared to them to be unjust, inefficient and backward, and the system and social forces and actors were pressurized and disrupted for systemic and psychological functioning. And it eventually led to discontent with the status quo.

As a result of these actions, a favorable structural situation was created for collective movement, instability and dissatisfaction. Then, since Iranian society was religious, Shiite Islam became popular as an alternative and popular belief. In the wake of this situation, the adverse performance of government agents and social control organizations, as well as the suppression of the Pahlavi regime as an accelerating factor of the revolution, played an important role in speeding up this mass movement. Ultimately, it was Ayatollah Khomeini's leadership role in the revolutionary mobilization that led to the formation of the Islamic Revolution with the conscious leadership and ideology of Shiite political Islam. The present text seeks to answer the question: How did the Pahlavi government's structural contexts influence the formation of the Islamic Revolution of Iran?

\section{THE STRUCTURAL BACKGROUND AND ITS IMPACT ON THE FORMATION OF THE ISLAMIC REVOLUTION OF IRAN}

Scholars have put forward a number of theories on the causes of the 1979 Islamic revolution led by Ayatollah Khomeini. Some consider economics, some despotism, some modernization, some foreign conspiracy, some mysticism and some religion to be the cause of this revolution. This article will explain the cause of the formation of the Islamic Revolution of Iran by emphasizing the structural backgrounds of the Pahlavi state in the framework of Smelser's theory of collective behavior in several stages.

As already mentioned, there are many structures in every society, and a revolution or movement occurs in a society when the appropriate structural background is provided for the revolution in that society. The pre-revolutionary Iranian society also had many structures. The Pahlavi government's actions triggered tension within these structures and created gaps and conflicts in them. These divisions created both dissatisfaction and injustice, and along with individual factors and the role of Khomeini's leadership, paved the way for the rise of the Islamic Revolution in Iran. In the following, we will examine these structures and their gaps and conflicts, and then Ruhollah Khomeini's movement and the accelerating factors towards the revolution, and finally, the revolution.

\subsection{The Status of the Political Structure}

There are many factors to consider regarding the political structure of Iran during the Pahlavi era; the first factor is the type of political system in Iran. Scholars have mentioned several types of political system in Iran, especially the Mohammad Reza era. Although the Iranian political system was based on the constitutional monarchy, some consider it patrimonial and some as neo-patrimonial (Afzali, 2007: 56; Zare', 2000: 289).

In Max Weber's view, "patrimonial is a late form of traditional systems and the result of changes in the construction of patriarchal power. In this way, with the development of the bureaucratic and especially the military system, the traditional patriarchal authority is transformed into an inherited and patrimonial system. Patrimonial domination is a traditionalism domination in which personal power is exercised, but neo-patrimonialism is an evolved form of patrimonialism. Thus, in the neo-patrimonial, the power is exercised without observance of tradition, relying on the tyranny and authority of the King, and it is outstretched according to the king's sovereignty and potency" (Weber, 1995: 350).

Characteristics of patrimonial regimes are: 1. Personalization of power and politics; 2. The primacy of the principle of closeness and faithfulness instead of meritocracy; 3. The informal power relations; 4 . The existence of balanced conflict in society; 5. The importance of militarism (Weber, 1995: 350). Such features should also be considered for neo-patrimonial regimes with the difference that in neo-patrimonial regimes: First, unlike patrimonial systems, for neo-patrimonialism the characteristic of religious justification of legitimacy is not of much importance and new elements such as pseudomodernization or external support are replaced by religion. Secondly, neo-patrimonial regimes have other features, including: apparent, superficial and exogenous modernization or quasi-modernization, the absolute power of the rulers, widespread corruption in the components of the system, the elimination all privileged groups from the political and social scene (blockage), including: groups of power, wealth and dignity, forgiveness and widespread gifts from the ruler.

Given these features and the research of scholars, it seems that after the fall of the Qajar government and the rise of Reza Shah, a neo-patrimonial political structure was created. "In the Qajar era, traditional policy based on patrimonialism was in place in Iran," says Jawad Sabbagh. This means that although King Qajar was at the center of the hierarchical circles of power, but the strong centralization and totalitarianism of the king did not mean that he had influence over all individuals and groups and all his entire territory. "(Sabbagh Jadid, 2007: 93).

Rasoul Afzali believes: "Unlike the Qajar era, the Pahlavi government had great power and influence and resolved the crisis of neo-patrimonialism through the use of repressive forces and modern bureaucracy. Reza Shah, and thereafter Mohammad Reza Shah, using external support and received revenues, created a repressive police force and expanded their own power and authority in a way that, as an active and powerful axis, they were in charge of all affairs related to many official elites in addition to being at the center of the hierarchy. Thus, the hierarchical patrimonial system became dictatorial neo-patrimonialism." (Afzali, 2007: 227-240). 
Another factor regarding the status of the political structure was the dependence of the Pahlavi regime. The August 28 coup against Mossadegh and Mohammad Reza's return to government, backed by US and British support, was the beginning of the creation of an affiliated government in Iran. "American support for the Shah and the creation of a Patron-follower relationship between Iran and the United States led to the Shah's government achieving a high degree of authoritarianism and independence from the social classes," says Mark J. Gasiorowski. As a result of this independence, the Shah's government had an irresponsible approach to internal social pressures, and its policies were out of the interests and needs of society. The Shah pursued certain economic policies that were often very inappropriate with Iran's economic conditions, for this reason, poverty and inequality persisted, and the oil boom of the $1970 \mathrm{~s}$, in addition to strengthening this independence of operation, was accompanied by abnormal mismanagement. Therefore, it did not improve the situation for the general public. The independence of government action enabled it to withstand the increasing pressure of the middle and lower class groups for social, economic and political change "(Gasiorowski, 1994: 199).

In Gasiorowski's view, "this relationship of Iran-US dependence, which strengthened the state and empowered it to achieve independence of action, acted as an external structural factor and prevented the role of the modern middle class and the new industrial working class in Iran. The modern middle class under Mossadegh's rule showed his superiority and ability to rule, and if external structural factors were not involved, this class could succeed, but the establishment of a state dependent on high independence of action disrupted the process and and made it easy for the regime to dominate parts of the modern middle class." (Gasiorowski, 1994: 435).

Another factor in the political structure was authoritarianism. Reza Shah's monarchy must be considered as the years of 1933-1941 and the period of Mohammad Reza's royal reign must be considered as the years 1955-1963. During these periods, father and son concentrated more on power and increased authoritarianism (Afzali, 2007: 91). Katooziyan argues in this regard: "The state had real ownership of land and capital, and therefore, always operated above the social classes and beyond the law" (Katooziyan, 1993: 14).

Lack of law, lack of social mobility, and lack of organized social institutions were the most important elements that sustained authoritarian rule and, to a large extent, impeded continued social, economic, scientific, and technological development.

Another factor in the political structure of the Iranian society was the rentier Pahlavi government. A rentier government is a government that receives significant amounts of foreign rents on a regular basis. The rentier government has the following characteristics: 1 .It is the principal recipient of the rent and naturally plays the most important role in the distribution and spending of the rent; 2 . The share of rent revenue in government revenue is more than $42 \%$ of total government revenue; 3 . In a rentier state a very small group of people in the community are involved in generating most of the wealth and income; 4. The source of the rent should be foreign, not domestic economic activity (H. beblawi, G. luciani, p. 11.12). In addition to the above, rent results in the independence of the state from society, the inability of the state to establish democracy and democratic institutions, and the transformation of the state into a distributor of rent and on the other hand, rent weakens social groups and the growth of bureaucracy in society. (Shekari, 2000: 66; Afzali, 2007: 103).

Most of the Pahlavi government's income, especially the second Pahlavi's, came from oil and oil dominated the Iranian economy, so a small percentage of the Iranian population contributed to this income. On the other hand, in the Pahlavi government, oil was always a minor factor in job creation and few people were working in the field. The share of the oil sector has also been much higher than other sectors such as agriculture, industry and services in GDP (Katooziyan, 1993: 164).

On the basis of these characteristics, it can be said that Iran had a rentier government during the reign of Mohammad Reza. Mohammad Reza, by dominating the oil resources, independent himself from other classes of society, and in this situation, some classes within the society became dependent on themselves because of their oil money and weakened some classes of society. It also created a system of state bureaucracy to distribute rent between classes and social groups, gain legitimacy and maintain political stability. The rentier Pahlavi government attracted some social groups, including the Comprador bourgeoisie, the new middle class, and some intellectuals in the political system, but at the same time, because of independence from social groups and pride in possessing oil revenues, it ignored traditional influential groups and social classes, including clerics and marketers.

\subsection{The State of the Economic, Social Structure}

As a result of the rapid growth or recession and accelerated modernization, there are changes in the stable statuses and stable social conditions of people, and people are drawn to large cities from different cities and villages with different cultures. In this situation, different people whit different cultural backgrounds gather in the city and different types of norms prevail. In such a situation, normative confusion occurs, and most people see existing formal norms as a major obstacle to achieving their goals and satisfying their needs. Therefore, they begin to oppose the official culture and start a revolution (Rafi'pour, 1999: 256-234).

According to the aforementioned, in the Iranian society before the revolution, urbanization and the development of higher education, were two factors of social change that created social disruption and normative turbulence, followed by economic, social and political inequalities in society. It caused the internal vulnerability of the social structure dominated 
and, as a result, created structural gap and Conflict in society. This practice paved the way for the convergence and mobilization of dissatisfied groups and, consequently, the revolution led by Ruhollah Khomeini.

Concerning educational centers in the Pahlavi era, especially in the second Pahlavi era, it should be acknowledged that the levels and centers of education have expanded and the number of schools and universities and students abroad has increased exponentially. Students studying at in-house universities, because of their student acceptance through the entrance exam, were mostly from poorer social classes who later became the focus of the fight against the regime. (Barry Rubin, 1984: 98), or, many university professors who were critical or opposed to the regime transferred their thinking to these students. In addition to the domestic students, there were 80,000 foreign students, whom Mohammad Reza intended to provide their specialist staff to run the country. These students were predominantly left-leaning, Islamist, and indigenous and, in the face of the West, their experience of living and teaching in the West and comparing it with the ineffective Pahlavi regime, discouraged them and organized associations and activities against the regime. Thus, although the Pahlavi political regime provided the appropriate educational, occupational, and material conditions for the educated and non-educated middle class, it was not politically able to provide the appropriate space for them and this procedure provided the basis for protest. Urbanization and renovation was another factor in the economic and social structural situation. The Shah's land reform in the 1961s transformed peasants into landless petty owners or wage-earners. As a result, the flood of rural immigrants into cities increased and urban population increased by 47\% (Abrahamian, 1999: 530). These immigrants who were trained for agricultural work, often turned to industry and service jobs in cities, but because they were largely illiterate, they could not be absorbed in office and industrial work, and thus turned to work and labor. On the other hand, due to their economic poverty and rising housing rent and housing shortages, some people created slums around the cities. Consequently, poverty and lack of space in modern or traditional social and economic environments transformed these individuals into disorganized masses and led them to protest and revolutionary developments (Kamali, 2002: 1951). Modernization, when it does not conform to the indigenous conditions and cultural, religious, political, social, and economic contexts of society, creates structural divisions and conflicts and creates social disruption. The Pahlavi government, especially Mohammad Reza Shah, had initiated a modernization program. Experts have considered several features for it, such as accelerated modernization, unbalanced and dependent development, authoritarian modernization, and pseudo-modernism. (Afzali, 2007: 110-53).

Given the increase in oil revenues since the early 1951s, the pace of modernization in Iran has become more hasty and ambitious. Instead of modernization being based on new infrastructure, it was built on an old structure. Due to the weakness of the old structure, it gradually showed its bottlenecks and, as a result, caused structural conflicts and social turmoil.

"At the time of the Pahlavi kings, especially Mohammed Reza, the domination of authoritarian rule on the economy gave him the freedom to pursue his economic priorities." Said Ervand Abrahamian. "In the field of modernization, the king, like his father, obeyed his ambitions and did not care about the opinion of experts. Therefore, as the economic policies of the government were subordinate to the king's priorities, not to the interests and needs of the community, so the disparities that had begun in the economic structure grew rapidly (Abrahamian, 1999: 613).

on the other hand, in the process of modernization that the king pursued, all the people and non-governmental elites were ignored. In this backward political situation, Politicians have tried to bring the political structural situation closer to centralized imperial structures. In such circumstances, there was a fundamental contradiction between the underdeveloped political structures and the economic and social structures that had emerged and somewhat evolved. It was bringing the community closer to a social explosion" (Abrahamian, 1999: 523).

Pahlavi governments were dependent on foreign governments. Reza shah's government was consolidated with the support of the British government, and Mohammad Reza Shah's government was consolidated with the American backing in 1953, and both created the foundations of an authoritarian government. Indeed, US economic and security assistance to Mohammad Reza Shah provided the basis for Mohammad Reza's authoritarianism. These aids increased both the ability of the government to suppress society and the ability to attract the people it wanted. This situation opened the way for the state to become more independent of society and further distanced the state from its social class and demands. (Kamali, $2002: 369$ and Lavasani, 1993:23 onwards).

In the view of the Rasul Afzali, such a situation enabled the government to implement policies that were always in the best interest of society and, consequently, fueled political unrest (Afzali, 2007: 75). This situation itself caused Structural Gap and Conflict in society and eventually provided the basis for the revolution.

Economic, social, and political inequalities are other causes of gap and Conflict in economic and social structures, and then protests. The income discrepancy was increasing between 1961 and 1978. Economic inequality had occurred at all levels, which means that in addition to the high and low levels of income distribution, the income gap between the city and the village had also increased. John Foran believes "The standard of living in urban areas was better than in rural areas, However, the majority of urban people were not comfortable living because of unequal distribution of income, inflation, and other problems, and although increased revenues from oil sales generally increased per capita income in Iran, But this increase in income did not raise the standard of living for all Iranians and the share of the lower classes of Iranian society in national income declined" (Foran, 2003: 491).

Abrahamyan calls regional inequality another type of inequality in Pahlavi regime's plans. He argues: "In the 1960s, Tehran had more than half its factories, while other parts of the country were lagging behind" (Abrahamian, 1999: 553-552). 
Through these actions, ethnic and class inequalities were created in society, resulting in structural gaps and conflicts in society and eventually led to dissatisfaction.

Concerning social inequalities in the Shah's regime, the inequality of the affluent and low-income classes of society was very high. Faramarz Rafi'pour writes: "The social justice system of the Shah was much more flexible than the social base of individuals, and formal laws and norms were less necessary for the upper class. This was unbearable for the middle class whose expectations had been heightened by modernization developments, leading to a sense of inferiority and deprivation, or the social concessions given by the Shah's regime to Americans living in Iran were very humiliating for the classes of Iranian Community." (Rafi' pour, 1996: 85). Thus, such inequalities were unacceptable in Iran's new structure and created structural gaps that provided the background for protest and revolution.

Politically, the political inequality in the regime was so high that the possibility of participation was minimal and sometimes unimportant, and decisions were dictated unilaterally from top to bottom. Political and economic positions were held by members of the royal family and their appointees, and there was no political competition between the official elite of the government and the elite outside of government and power. In other words, the parliamentary elections were a demonstration. Javad Sabagh writes: "Intolerance with the opposition and the elimination of other parties and groups, including the National Front, the Tudeh Party, the volunteer of Islam (the Fedaeis of Islam) or the deportation of Ayatollah Khomeini, all signaled the closure of the political space and the non-participation of groups, parties and people in political matters. (Sabbagh Jadid, 2007: 158).

Thus, in the process of comparing economic, social, and political inequalities between rural, deprived areas, low-income classes and middle-class of society with the affluent classes in urban areas, a sense of deprivation emerged. These factors subsequently created a structural gap and conflict in society and spontaneously provided grounds for protest.

\subsection{Structural Cultural and Religious Status}

Compared to other societies, the Iranian society has a special status in the cultural and religious fields, and this special situation has provided a favorable situation for the formation of popular collective movement and fundamental changes in social and political life. Nikki R. Keddie considers the Iranian society to have features that make it more revolutionary than other Third World countries, with the exception of China. He regards Iran and China as countries with long cultural identities and in approximately similar contexts (Keddie, 1999: 221 to 238). He sometimes considers Iranian identity more as Shiite than national change. In Shiite texts and themes, there are many concepts such as the subject of duality of good and evil, right and wrong, cruelty and justice. After the long-period absence of Imam Mahdi (the person promised in the Shiite texts), the Shiites temporarily lost their claim to political power. Later, with the emergence of the Al Bouyeh dynasty, many Shiites, who were at least under attack, were encouraged to immigrate to Iran. Before the rise of the Safavid Empire, most Iranians were Sunni (Niyazmand, 2004: 45).

In 880 (1501 AD), the Safavid Empire came to power in Iran and King Ismail declared Shiite religion the official religion of Iran (Niyazmand, 2004: 41). He invited Shia scholars to Iran. Most of these scholars accepted Shah Ismail's substitution and legitimized his political and religious domination. Thus, the history of Iran from the Safavid period to the late Qajar era had a dual discourse of authority divided between religion and government. With the formation of the Safavid state, the absence of a strong and independent Iranian government after the Arab invasion to Iran was eliminated as the most important crisis threatening Iran's long-standing identity. By proclaiming Shiite religion as the official religion, the Safavid government was able to transform the Shiite faith into an ideological framework as a political plan to create Iranian community identity. In addition to designating Shiite religion as the country's religion, the Safavids adopted the old form of the Iranian government or monarchy and called themselves Shah's (Kamali, 2002: 51).

The formation of this Shiite government had some social implications for Iranian society, such as the empowerment of Shiite clergy and their connection with political authority, the widespread influence of Shiite religion on the Individual and Social Life of the Iranian People, And the formation of a traditional religious community consisting of Shiite clerics and marketers who were regarded as groups that were opposed to the state and substantially independent of the state. These implications had maintained their identity as the dominant culture in Iran until the late Qajar period. Thus, from the Safavid era, a cultural-religious structure was formed in Iran, elements of which were Iranian national identity and Shiite religion. This structure continued until the Qajar period, but through the Pahlavi era and through their actions, a gap emerged in these structures and According to Nikki Keddie: "There was a phenomenon called biculturalism whose distinctive characteristic was the cultural dichotomy between the culture of the privileged classes and the elites with deprived classes and masses of people" (Keddie, 1990: 275).

After traveling to Turkey, Reza Shah rejected the cultural and religious values and patterns of Iranian society and made great efforts to incorporate Western behavioral and ethical patterns and values into Iranian society. This Process continued during the reign of Mohammad Reza, and the patterns of Western society became widespread in Iranian society. In such a situation, a kind of biculturalism was prevalent in Iranian society. In the culture and ethics of the High and affluent social classes, reading Western novels and installing images of Western artists and heroes in homes and halls was a sign of Progress and modernization, and whatever religious and Iranian color and national culture was, it was a sign of backwardness. "Just as much the new upper and middle classes were westernized and their behavior different from Iranian and Islamic values, the traditional lower and middle classes regarded the royal family and the upper class as immoral and un-Islamic," says Mark J. Gasiorowski. As a result of this situation, there was a growing gap and conflict between the 
values and social habits of the modern and western sectors and traditional sections of Iran. This was the factor that alienated the traditional part of society from its new part" (Gasiorowski,1994: 409-407).

Alongside such a situation, the widespread presence of foreign forces, especially the ones of the United States, in Iran considering as a form of identity invasion, made Iranian people get a strong sense of preservation of their unity and values, under the influence of their national and religious culture as well as the righteous aspects of Shiite culture, which ended in a mass movement, protest, and revolution.

Therefore, the actions of the Pahlavi government activated the stressful factors and created huge gaps and conflicts in the structures of Iranian society, and these gaps created many pressures and stresses on the components of Iranian social life. Given that in the event of a fracture and conflict in any society, many structural pressures and tensions will automatically enter into the social life of that community, and it is followed by beliefs in the community to identify the causes of these pressures and provide a model for eliminating these pressures as well. Therefore, after creating gaps and conflicts in Iranian society, various models and ideologies began to identify the sources of gaps and conflicts and provide a suitable model for the future life of Iranian society. These patterns included: liberalist, socialist, Marxist, nationalist, and Shia Islam.

Among these patterns, Shiite Islam had a long history in the culture and civilization of Iranian society and was one of the foundations of Iran's traditional discourse. Therefore, the former regime tried to marginalize it. However, because of its intrinsic content and having a familiar presentation and form for Iranian community, it could introduce itself a comprehensive revolutionary ideology as a more generalized model that offers a better future for the people. The analysis of historical events and Shiite personalities, especially the Shiite Imams and their testimony, were raised as symbols and examples of the struggle against tyranny and authoritarian rule. By analyzing the uprising of Imam Hussein (AS), Ruhollah Khomeini introduced to the people the way to fight the Shah's rule. (For study, Madani, 1990: vol 2).

In the revolutionary readings by Ruhollah Khomeini and Dr. Ali Shariati of the Ashura event, Imam Hussein (AS) was introduced as a symbol of freedom, courage, patience and the fight against injustice. In general, the religious beliefs offered by Ruhollah Khomeini and Dr. Shariati had the following characteristics: Spiritualism, perfectionism, divine closeness, justice and the rejection of social, economic inequalities, the defense of the deprived, the fight against colonialism and exploitation, and the recognition of the rights of nations and freedom.

Finally, Because of these features in Ruhollah Khomeini, he became known as a model of fighting cruelty and a practical model of Islam and a fighter against the Pahlavi regime. That is why Islam as a generalized model under the leadership of Ruhollah Khomeini provided a favorable ground for public mobilization, collective action, and the fight against the Pahlavi government.

Along with the acceptance of Shiite Islam as a general model for collective action and protest, other factors accelerated this collective action and protest. These factors consolidated and objectified Islam and exposed the weakness and oppression of the Pahlavi regime, and thus contributed to the formation of the Islamic Revolution. The following factors were instrumental in the formation of mass action and popular protest: Attack of the regime forces on the people of Qom and Faizieh's students in February 1962, Mohammad Reza Shah's Offensive Lecture in Qom in 1962, the attack of regime Agents at Faiziyah school in April 1963; The arrest of Ruhollah Khomeini in June 1963 that led to the June 15 uprising, speech of Ruhollah Khomeini in November 1964 against the adoption of the capitulation bill, the publication of Ahmad Rashidi Motlaq's article against Ruhollah Khomeini, Bloody incident on Friday September 17, 1977 and the escape of Shah in 1998 (Niyazmand,2004: 57-60).

According to what has been said, the accelerating factors are the factors that consolidate and legitimize the generalized patterns and by them the weakness and injustice of the political system are identified. These factors lead society toward mass mobilization and then public protest. In fact, once structural conflicts and gaps have appeared in society and injustice has been manifested in all structures and grounds for mass movement and protest have been provided, these are accelerate factors that accelerate the process of protest and mass movement; however, this mass movement requires organization and leadership to accelerate the process of protest. It was Ruhollah Khomeini's role to emphasize the generalized pattern of being able to organize, lead, and mobilize people in protest and mass movement. As analysts of the Islamic Revolution have acknowledged, the Iranian revolution was a popular revolution to overthrow the Pahlavi regime (Foran, 2003: 576). In this revolution, militant clerics have played the role of organizing and leadership, marketers had the role of supporters of economy, intellectuals and students were in the field of outreach and awareness, and of the working and deprived classes of the society were responsible for revolutionary forces.

In terms of organization, the Islamic Revolution of Iran had a religious and collective organization (Religious Board) (Zibaklam, 1993: 267), and in addition to the board and the clergy network, the role of religious traditions in Iran, the mosques, the role of Ruhollah Khomeini, and the function of the Voice recorder tape were general factors in shaping popular movement. Ruhollah Khomeini made a major shift in Shia political jurisprudence. He gave the Shiite clergy and Authority a revolutionary and militant face, expanded the theory of Velayat-e Faqih and emphasized the necessity of establishing an Islamic state (Barkhordari, 2020(c):68). The role of the Voice recorder tape in the spread of revolutionary Shiite Islam was crucial because not everyone could read the proclamations, nor could they always be near with leaders and ideologies. Therefore, the use of this tool was very important.

Alongside the issue of organizing the revolution, the role of the leadership of the revolution and its organization is very important. The role of Ruhollah Khomeini is unquestionable from the year 1963 until the time of the revolution and most scholars have confirmed his decisive role in the revolution. Ruhollah Khomeini first of all laid the foundation for the 
revolution. He began the preparations for the revolution and the theoretical struggle against the Pahlavi regime in 1944 on the basis of jurisprudential and rational rules and writing the book of Kashf-alasrar. According to Khomeini, Islamic scholars needed to feel responsible for the formation of the Islamic state. Since 1963, he has openly entered into an open struggle with the Shah's regime (Niyazmand, 2004: 55).

The leadership of the struggle against the Shah's regime was practically manifested in the person of Ruhollah Khomeini and had been the leader of the movement since 1963, but historically Khomeini's struggle was more than thirty years old.; Khomeini saw both the September 1941 and the nationalization of the oil industry in 1953 as opportunities to overthrow the monarchy and establish an Islamic state (Imam Khomeini, vol. 3: 382.)

He also opposed the founding of the Constituent Assembly in 1948, the trial and execution of members of the Devotees of Islam ( Fada'i Islam), and the ratification of the state and Provincial Association Bill. Khomeini's decisiveness and inflexibility was one of his features in leading the revolution. In this regard, Barry Rubin argues: " If Ayatollah Khomeini had not been the leader of the Iranian revolution, and if it had not been for his tenacity and inflexibility, the Iranian revolution would probably not have led to the fall of the Shah" (Rubin, 1976: 197).

Finally, what led to the victory of the Islamic Revolution of Iran led by Ayatollah Khomeini to Shiite Islamic worldview was the inability of the social control system or the repressive apparatus of the Shah's regime. The Shah's regime could not to effectively use the repressive apparatus to suppress the Iranian people's revolutionary movement, and his army became neutral in the last days of the regime's life. The escape of the soldiers from the garrison, their refusal to shoot, declare solidarity a group of militias with the revolution and the neutrality of the army, all formed before the victory of the revolution and demonstrated the inability of the regime's military machine to suppress the revolutionary movement. ${ }^{1}$

\section{CONCLUSION}

The traditional discourse consisting of the two pillars of religion (Shiite religion) and the state was dominated on Iranian society for many years (Barkhordari, 2020(c):58). This discourse was attacked by the modern world during the Iran-Russia war, and modernity was forcibly introduced into Iranian society (Barkhordari, 2020(b):45). With the introduction of the components of the modern world into Iranian society, the traditional discourse gradually shook and its foundations (especially the Shiite religion as an influential foundation in Iranian politics) became unstable. In such circumstances, some people in Iranian society and some statesmen and intellectuals slowly embraced modernity. With the takeover of the government by the Pahlavi dynasty and Reza Shah's trip to Turkey and the study of Mohammad Reza Shah in the West and the acquaintance of both with the West, the process of entering the modern world into Iranian society intensified. The actions of the Pahlavi government in accelerating the entry of components of the modern world caused the complete shaking of the foundations of traditional discourse, especially the Shiite religion on the one hand and the shaking and destruction of some traditional structures in traditional Iranian society on the other hand. The actions of the Pahlavi government in destabilizing the traditional structures in Iranian society activated the tension factors within these structures. Due to the activation of stressors within the structures of society, these structures became conflicted and gap. These gaps and conflicts provided a favorable structural backgrounds for the formation of a collective movement in Iran and led to the emergence of social forces and then dissatisfaction and conflict of interest and put a lot of pressure on Iranian society and its social forces and finally led to the formation of the 1979 Iranian revolution. The important point in this process is that on the one hand, Shiite and revolutionary Islam led by Ayatollah Khomeini (in a period when modernity is accepted by the countries of the world) is accepted as a generalized belief by the Iranian society(A belief that declared the state of structural gaps and conflicts unfavorable and oppressive and portrayed a good situation for the Iranian people in the future), and on the other hand this religion (Shiite Islam) as one of the foundations of the traditional discourse of Iranian society previously attacked by Modernity and the components of the modern world had been able to rebuild itself and to dominate Iranian society after the 1979 revolution by preparing political jurisprudence as the ideology of governing society.

\section{REFERENCES}

Abrahamian E., (1999) Iran Between Two Revolutions, Translated by Ahmad Gol Mohammadi and Mohammad Ebrahim Fattahi, Tehran, Ney Publishing.

Azadanloo H., (2007) Introduction to the Basic Concepts of Sociology, Tehran, Second Edition, Ney publishing.

Afzali R., (2007). Modern State in Iran, Qom, Mofid University Publishing.

Akhavan Mofrad R., (2002) Ideology of the Iranian Revolution, Tehran, Imam Khomeini Research Institute and Islamic Revolution Publishing.

1 - For further study: Lotfian, 2001: 322; Zunitz, 1991: 496; and Naraghi: 1993, 154. 
Basharieh., H. (2014). Revolution and Political mobilization. Tehran: University of Tehran Press.

Barkhordari, A. (2020.a). Rethinking Two Scientific Currents, Westernism and Philosophical Orientation, in Iran of the Islamic Republic Era. Journal of Sociological Research. V, 11.N, 2. P 23-38. https://doi.org/10.5296/jsr.v11i2.17008

(2020.b). Ntionalism in the Thought of the First Modern Thinkers of Iran. International Journal of Advanced Research in Management and Social Sciences.V, 9. Issue, 3. P, 31-48.

(2020.c).Systematization and the Model of Political Management in Contemporary Iranian Thinker's Idea.Journal of Social Science Studies 7 (2), 57-71. https://doi.org/10.5296/jsss.v7i2.16937

Beblawi H. luciani G. (1997). The rentier state. London: cromhelm

Cohen B J., (2005) Introduction to Sociology, translation by Gholam Abbas Tavassoli and Reza Fazel, Tehran, 16th Edition, Samt publication.

Foran J., (2003) Fragile resistance: Social transformation in Iran from 1500 to the revolution, translation by Ahmad Tadayin, Tehran, Fourth Edition, Rasa publishing.

Goldi J and Columbus W L., (1997) A dictionary of the social sciences, Mustafa Azkia and others, Tehran, first edition, Maziar publishing.

Gasiorowski M J. (1993) U.S. Foreign Policy and the Shah: Building a Client State in Iran. Jamshid Zanganeh, Tehran, Rasa publishing.

Hakimi M R., (2010) the Interpretation of the Sun. Tehran, Islamic Revolution Documentation Center Publishing.

Katouzian M A H., (2002) Nine Articles in Iranian Historical Sociology, translation by Alireza Tayeb, Tehran, Second Edition, Qomes publishing.

Papyrus publishing.

., (1993) Iranian Political Economy. Translated by Mohammad Reza Nafisi and Kambiz Azizi, Tehran,

Keddie N.R., (1989) Roots of Revolution: An Interpretive History of Modern Iran, translated by Abdul Rahim Gavahi. Tehran, Pen publishing.

-(2010) Why Has Iran Been Revolutionary?, Trans Fardin Qureshi, Matin Magazine, No. 2.

Kamali M., (2002) Civil Society, State and Modernization in Contemporary Iran, Tehran, open publishing.

Lavasani S.,(1993) State and Government in Iran, Tehran, Language pile of books Publishing.

Lotfiiyan S.,(1999), Army and Islamic Revolution of Iran, Tehran, First Edition, Islamic Revolution Documentation Center Publications.

Madani J., (1989) Contemporary Iranian Political History, Qom, Vol. 2, Islamic Publications Office.

Mousavi Khomeini R., Sahifah Noor, Imam Khomeini Publishing Institute, Tehran, vol. 1 and 3.

Moein., M. (1981). Persian Dictionary. Vol. 1. Tehran: Amirkabir Publications.

Moshirzadeh., H. (1995). A brief look at the theories of revolution in the social sciences, the Islamic Revolution and its roots. Collection of articles (1), Qom.

Niyazmand R., (2004) Shiites in Iranian History, Tehran, Hekayate Galam Novin publication.

Naraqi E., (1993) From Palace to Prison: Inside the Iranian Revolution, translated by Saeed Azari, Rasa publishing.

Ricardo D.,(1995) On The Principles of Political Economy and Taxation, translation by Habibolah Teymouri, Ney publishing chapters 2,3 , and 5 .

Rubin B., (1363) The War of Powers in Iran, translation by Mahmoud Mashraqi, Tehran, First Edition, Ashtiani Publications.

Rafi Pour F.,(1996) Development and Conflict, Tehran, Shahid Beheshti University Press. 
-(1999) Social Anatomy, Introduction to Applied Sociology, Tehran, stock company Publishing.

Rajabloo., A.(1996). A Theoretical Reflection on the Concept of Revolution, Presence journal, No. 16. Http: //ensani.ir/fa/article/53620.

Sabagh Jadid J.,(2007) The Islamic Revolution of Iran a Movement of Value, Tehran, Documentation Center of the Islamic Revolution publishing

Shekari A Q.,(2000).Theory of the Educated State and the Islamic Revolution, Tehran Revolutionary Documentation Center.

Smileser N.,(2001) Theory of Collective Behavior, translation by Reza Dezkam, Tehran, New Findings Publishing.

Strauss. L. (1994). What is political philosophy? Trans Farhang Rajaee. Tehran: Scientific and Cultural Publications.

Vahdat F., (2003) God and jaggernaut: Iran's intellectual encounter with modernity, translation by Mehdi Haghighatkhah, Tehran, Phoenix publication.

Weber M.,(1995), Economy and Society, Abbas Manouchehri and Mehrdad Torabi Nadzad and Mostafa Emadzadeh, Tehran, Mola publication.

Zare A., (2000) the Last Revolution of the Century, Qom. First Edition, Maaref Publications, Vol 1.

Ziba Kalam S., (1993) an Introduction to the Islamic Revolution, Tehran, First Edition, Roozana.

Zonis M., (1991) Majestic failure: the fall of the Shah, Translated by Ismaeil Zandi and Batuol Saeedi, Tehran, Noor Publishing. 